\title{
Impact of Raised Troponin in Older Patients in the Presence or Absence of Coronary Artery Disease
}

\author{
Nancy Wassef ${ }^{1 *}$, Javed Ehtisham², Neeta Patel3, Naeem Shaukat ${ }^{2}$ \\ ${ }^{1}$ Queen Alexandra Hospital, Portsmouth, United Kingdom \\ ${ }^{2}$ Kettering General Hospital, Northamptonshire, United Kingdom \\ ${ }^{3}$ Leicester Royal Infirmary, Leicester, United Kingdom
}

"Corresponding author: Nancy Wassef, Department of Cardiology, Flat 12, Connaught House, Queen Alexandra Hospital, Portsmouth, PO63 LY, UK. Tel: + 447427490643; Email: nancy.wassef@gmail.com

Citation: Wassef N, Ehtisham J, Patel N, Shaukat N (2017) Impact of Raised Troponin in Older Patients in the Presence or Absence of Coronary Artery Disease. Cardiolog Res Cardiovasc Med 2: 120. DOI: 10.29011/2575-7083.000020

Received Date: 12 July, 2017; Accepted Date: 24 August, 2017; Published Date: 30 August, 2017

\begin{abstract}
Objective: Recent data has suggested an increased risk for patients with raised troponin, but prognosis of older patients with non-obstructive Coronary Artery Disease (CAD) is still unknown.

Methods: A retrospective cohort analysis was performed for all in-patients with raised troponin T (January 2010 to December 2011, $\mathrm{n}=1351), 858$ above the age of 65 were studied. Of these, 513 had angiography and they were stratified according to their coronary arteries anatomy into older obstructive CAD ( $\geq 50 \%$ stenosis) (OO- CAD, 448, 87.3\%) and older non-obstructive $(<50 \%$ stenosis) (ONO-CAD, 65, 12.7\%). The 345 patients who had no angiography were followed separately for their outcome. The risk of death and Major Adverse Cardiac and Cerebrovascular Events (MACCE) rates at one year, were calculated for the older groups who had angiography and these were compared to the total patients who received angiograms for raised troponin.

Results: The mean age was similar between both older groups (77.9 \pm 6.95 Vs.76.9 $\pm 7.02, \mathrm{P}=0.236)$. The one-year MACCE rate was similar in both the ONO-CAD and OO-CAD group (one-year MACCE: RR [95\% CI] $=1.01$ [0.61-1.66], $\mathrm{P}=0.95$ ). This was driven by the acute coronary syndrome patients who had unplanned revascularization and stroke. The one-year mortality was equal in ONO-CAD and OO-CAD group with a $\mathrm{RR}[95 \% \mathrm{CI}]=1.48[0.81-2.7], \mathrm{P}=0.19$. This was similar to the total patient groups mortality at one- year with a $\mathrm{RR}[95 \% \mathrm{CI}]=0.93[0.53-1.64], \mathrm{P}=0.8$.
\end{abstract}

Conclusion: Older patients with a raised troponin and non-obstructive CAD are at equivalent MACCE \& mortality risk at one year to those with obstructive CAD.

\section{Introduction}

Previous studies have been performed evaluating the significance of a raised troponin in both ischemic heart disease and noncardiac conditions [1]. While it has been found that cardiac troponins are valuable in the diagnosis of Acute Coronary Syndromes (ACS), it has also been shown to be elevated in other cardiac (e.g., heart failure, myositis) and non-cardiac conditions (e.g., sepsis, renal failure, pulmonary embolism) $[2,3]$.

The prognosis of older patients ( $>$ than 65 years of age) with nonobstructive coronary artery disease is unknown. Previous studies, has shown that patients with raised troponin and non-obstructive CAD have an increased risk of death and Major Adverse Cardiac and Cerebrovascular Events (MACCE) at 1-year follow-up [4-6]. This study was performed to further investigate the outcomes of older population who present with positive troponin and had nonobstructive CAD.

\section{Methods}

A retrospective cohort analysis was performed, which included all in-patients who had a raised cardiac troponin T (cTnT; AQT90 FLEX [Radiometer Medical ApS, Brønshøj, Denmark], 


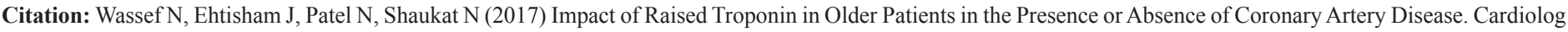
Res Cardiovasc Med 2: 120. DOI: 10.29011/2575-7083.000020

using the 99th percentile value of $0.017 \mathrm{ng} / \mathrm{ml}$ with limit of detection has been determined to be $0.010 \mu \mathrm{g} / \mathrm{L}$ ) presenting to Kettering General Hospital, from January 2010 to December 2011 [7]. All troponin positive acute coronary syndrome patients were included (ST Elevation Myocardial Infarction (STEMI) and Non-ST Elevation Myocardial Infarction (NSTEMI) patients. The patients who had no angiography were subdivided by age and if were more than 65 years old, they were grouped as older no angiography (O-NA) and their outcome was followed separately. The remaining total patients were grouped according to their coronary anatomy into obstructive CAD ( $\geq 50 \%$ stenosis in their coronary arteries) and non-obstructive $\mathrm{CAD}(<50 \%$ stenosis $)$ [8-10].

Further subdivision of the patients above the age of 65 , into Older Obstructive CAD (OO-CAD) and Older Non-Obstructive (ONO-CAD) according to the presence of $\geq 50 \%$ stenosis in their coronary vessels, or $<50 \%$ stenosis, respectively.

The relative risk of death at one month and one year, were calculated for the older groups and were compared to the total patient groups. The MACCE rates were also compared and this was defined as death, myocardial infarction, unplanned revascularisation and stroke/Transient Ischemic Attacks (TIA).

Furthermore, the prevalence of frailty was assessed clinically, in the patients who had no angiography (O-NA) and the patients who had no obstructive CAD by their treating physicians and cardiologists.

\section{Statistical Methods}

The data were analyzed with the use of MedCalc version 12.7.2 (MedCalc Software bvba, Ostend, Belgium). The results were expressed as percentage or mean \pm standard deviation for categorical and continuous variables, respectively, due to normal population distribution. Significant differences between groups were assessed by $\chi 2$ test and Student's t test in comparing between nominal and continuous variables, respectively. One-way analysis of variance test was used instead of Student's t test in cases of more than two quantitative variables. Significance was ascribed with probability $<0.05$.

\section{Results}

A total of 1351 patients who presented to Kettering General Hospital with raised cTnT (more than $0.010 \mu \mathrm{g} / \mathrm{L}$ ) from January 2010 to December 2011, were included in the study. The patients above the age of 65 were 858 , from them 345 were followed separately as they had no coronary angiograms and were medically managed. These patients were excluded from having angiography due to different reasons like frailty, acute renal impairment and other multiple comorbidities and they were medically managed. The frailty was found in $281(81.4 \%)$ of the older patients who had no angiography (O-NA group).
The rest of the older patients were 513 who had coronary angiography were stratified anatomically into obstructive CAD (OOCAD, 448, 87.3\%) and non-obstructive (ONO-CAD, 65, 12.7\%) according to the presence or absence of $\geq 50 \%$ stenosis in their coronary vessels [8-10]. Frailty was found in $(29,44.6 \%)$ of the older non-obstructive group (ONO-CAD group). (Figure 1)

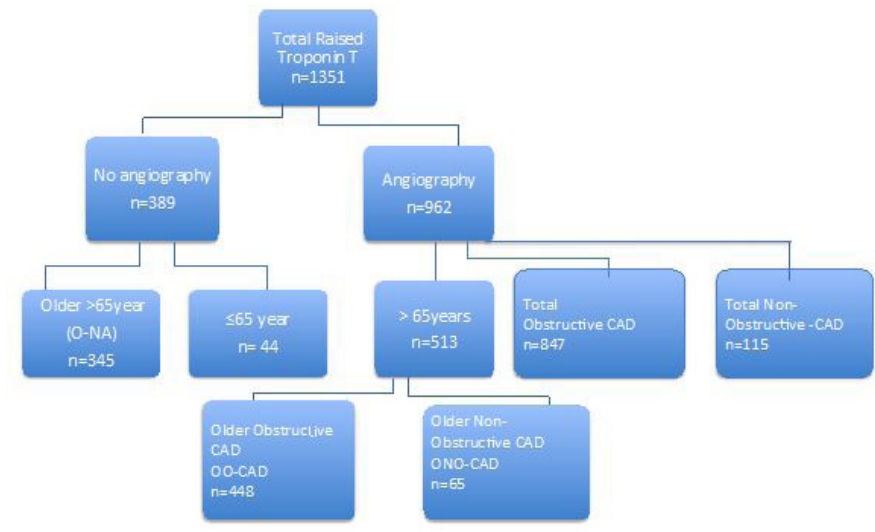

Figure 1: Flow chart showing the total and older patients numbers and subdivision.

Also, the 962 total patients who had coronary angiography were grouped according to the presence of presence of $\geq 50 \%$ stenosis into obstructive CAD (847.88\%) and non-obstructive $(115.12 \%)$ with $<50 \%$ stenosis [8-10]. In the total non-obstructive CAD group frailty was found to be $26.9 \%$, in 31 patients. (Figure 1 )

The mean age was similar between both older groups who had angiography $(77.9 \pm 6.95 \mathrm{Vs} .76 .9 \pm 7.02, \mathrm{P}=0.993)$ and there were more females in the non-obstructive group $(56.9 \% \mathrm{Vs} .32 .8 \%$, $\mathrm{P}=<0.0001)$ and moremales in the obstructive group $(43 \% \mathrm{Vs} .67 .1 \%$, $\mathrm{P}=0.0024)$. The mean troponin T level was lower in the older nonobstructive group $(0.5 \pm 0.6$ Vs. $2.0 \pm 3.5, \mathrm{P}=0.096)$. Risk factors for $\mathrm{CAD}$ were similar except for more smokers were found in the ONO-CAD group (13.8\% vs. 4.6\%, $\mathrm{P}=0.0039)$. (Table 1$)$

\begin{tabular}{|c|c|c|c|}
\hline & $\begin{array}{c}\text { Non-Obstruc- } \\
\text { tive (ONO- } \\
\text { CAD) } \\
\text { N=65(12.7\%) }\end{array}$ & $\begin{array}{c}\text { Obstructive } \\
\text { CAD (OO- } \\
\text { CAD) } \\
\text { N=448 }(87.3 \%)\end{array}$ & P value \\
\hline Age & $77.9 \pm 6.9$ & $76.8 \pm 7$ & 0.236 \\
\hline Gender & $28(43 \%)$ & $301(67.1 \%)$ & $\begin{array}{c}0.0024 \\
147(32.8 \%)\end{array}$ \\
\hline $\begin{array}{c}\text { Male } \\
\text { Female }\end{array}$ & $37(56.9 \%)$ & 106001 \\
\hline $\begin{array}{c}\text { Diabetes Mel- } \\
\text { litus }\end{array}$ & $12(18.4 \%)$ & $23.6 \%)$ & 0.1209 \\
\hline Hypertension & $45(69.2 \%)$ & $277(61.8 \%)$ & 0.2123 \\
\hline Smoker & $9(13.8 \%)$ & $21(4.6 \%)$ & 0.0039 \\
\hline
\end{tabular}




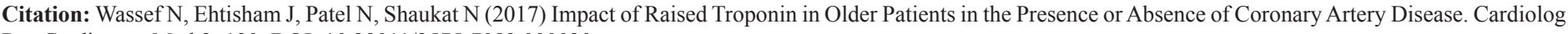
Res Cardiovasc Med 2: 120. DOI: 10.29011/2575-7083.000020

\begin{tabular}{|c|c|c|c|}
\hline Ex-smoker & $5(7.6 \%)$ & $51(11.3 \%)$ & 0.3831 \\
\hline Dyslipidaemia & $42(64.6 \%)$ & $264(58.9 \%)$ & 0.3564 \\
\hline $\begin{array}{c}\text { Family History } \\
\text { for CAD }\end{array}$ & $1(1.5 \%)$ & $4(0.89 \%)$ & 0.6240 \\
\hline
\end{tabular}

Table 1: Demographics and risk Factors for CAD older groups with angiography.

The comparison for anemia and renal impairment with baseline hemoglobin and kidney functions showed no difference between both OO-CAD and ONO-CAD groups. (Table 2)

\begin{tabular}{|c|c|c|c|c|}
\hline & & $\begin{array}{c}\text { Older } \\
\text { Obstructive } \\
\text { CAD (OO- } \\
\text { CAD) } \\
\mathrm{N}=448 \\
(87.3 \%)\end{array}$ & $\begin{array}{c}\text { Older } \\
\text { Obstructive } \\
\text { CAD (OO- } \\
\text { CAD) } \\
\mathrm{N}=448 \\
(87.3 \%)\end{array}$ & $\mathrm{P}$ value \\
\hline \multicolumn{2}{|c|}{ Haemoglobin +} & $12.1 \pm 1.7$ & $12.5 \pm 1.9$ & 0.249 \\
\hline \multicolumn{2}{|c|}{ Creatinine $^{\circ}$} & $110 \pm 73$ & $106 \pm 58$ & 0.612 \\
\hline \multicolumn{2}{|c|}{$\begin{array}{l}\text { GFR * and } \\
\text { grade of renal } \\
\text { impairment• }\end{array}$} & & & \\
\hline GFR & $>60$ & $34(52.3 \%)$ & $\begin{array}{c}268 \\
(59.8 \%)\end{array}$ & 0.2814 \\
\hline IIIa & $45-59.9$ & $16(24.6 \%)$ & $89(19.8 \%)$ & 0.3655 \\
\hline IIIb & $30-44.9$ & $8(12.3 \%)$ & $66(14.7 \%)$ & 0.6075 \\
\hline IV & $15-29.9$ & $5(7.6 \%)$ & $21(4.6 \%)$ & 0.3017 \\
\hline $\mathrm{V}$ & $<15$ & $1(1.5 \%)$ & $4(0.89 \%)$ & 0.624 \\
\hline
\end{tabular}

Table 2: Baseline anemia and renal impairment.

The echocardiographic findings showed that the ONO-CAD group had more evident structural abnormalities than the patients who had OO-CAD, including left ventricular systolic dysfunction, aortic valve disease and left ventricular hypertrophy. (Table 3) The left ventricular diastolic function was assessed by echocardiography in the non-obstructive CAD patients. Diastolic dysfunction was found in $26.1 \%$ of the ONO-CAD group in comparison to $17.4 \%$ in the total non-obstructive $\mathrm{CAD}$ group $(\mathrm{P}=0.16)$.

\begin{tabular}{|c|c|c|c|}
\hline & $\begin{array}{c}\text { Older Non- } \\
\text { Obstructive } \\
\text { (ONO- } \\
\text { CAD) } \\
\mathrm{N}=65 \\
(12.7 \%)\end{array}$ & $\begin{array}{c}\text { Older } \\
\text { Obstructive } \\
\text { CAD (OO- } \\
\text { CAD) } \\
\mathrm{N}=448 \\
(87.3 \%)\end{array}$ & $P$ value \\
\hline No structural heart disease & $22(33.8 \%)$ & $3(0.6 \%)$ & $<0.0001$ \\
\hline $\begin{array}{c}\text { Severe/Moderate aortic valve } \\
\text { disease }\end{array}$ & $7(10.7 \%)$ & $4(0.8 \%)$ & $<0.0001$ \\
\hline Moderate to severe LVH & $5(7.6 \%)$ & $3(0.6 \%)$ & 0.0007 \\
\hline $\begin{array}{c}\text { Severe LV systolic impair- } \\
\text { ment }(\mathrm{EF}<35 \%)\end{array}$ & $7(10.7 \%)$ & $12(2.6 \%)$ & 0.0023 \\
\hline \multicolumn{4}{|l|}{$\begin{array}{l}\text { Moderate LV systolic impair- } \\
\text { ment (EF44- }\end{array}$} \\
\hline $35 \%)$ & $10(15.3 \%)$ & $13(2.9 \%)$ & $<0.0001$ \\
\hline $\begin{array}{l}\text { Mild LV systolic impairment } \\
\text { (EF 45-55\%) }\end{array}$ & $6(9.2 \%)$ & $8(1.7 \%)$ & 0.0017 \\
\hline $\begin{array}{l}\text { Regional wall motion abnor- } \\
\text { mality }\end{array}$ & $10(5.3 \%)$ & $19(4.2 \%)$ & 0.0005 \\
\hline \multicolumn{4}{|c|}{ Hypertrophic cardiomyopathy } \\
\hline (Confirmed by CMR) & $0(\%)$ & $0(\%)$ & \\
\hline Takotsubo cardiomyopathy & $1(1.5 \%)$ & $0(\%)$ & 0.0639 \\
\hline $\begin{array}{l}\text { Moderate to severe valvular } \\
\text { heart disease }\end{array}$ & $2(3.0 \%)$ & $1(0.2 \%)$ & 0.0312 \\
\hline \multicolumn{4}{|l|}{ Others } \\
\hline $\begin{array}{l}\text { (Right ventricular function } \\
\text { impairment, pulmonary } \\
\text { hypertension, ASD, VSD or } \\
\text { previous valve replacement) }\end{array}$ & $6(9.2 \%)$ & $4(0.8 \%)$ & 0.0002 \\
\hline No echocardiogram & $4(6.1 \%)$ & $381(85 \%)$ & $<0.0001$ \\
\hline
\end{tabular}

Table 3: Echocardiographic findings.

The 30 days MACCE and mortality rates were similar between the ONO-CAD and OO-CAD groups [30 days MACCE: $\mathrm{RR}(95 \% \mathrm{CI})=1.21(0.62-2.3), \mathrm{P}=0.56 ; 30$ days all-cause mortality: $\mathrm{RR}(95 \% \mathrm{CI})=1.17(0.59-2.6), \mathrm{P}=0.69]$. This was similar when compared to the total patient's groups who had angiography (30 days MACCE: RR $(95 \% \mathrm{CI})=0.7$ (0.29-1.77), $\mathrm{P}=0.47 ; 30$ days all-cause mortality: RR $(95 \% \mathrm{CI})=1.24(0.54-2.86), \mathrm{P}=0.61)$. (Table 4 and 5) 


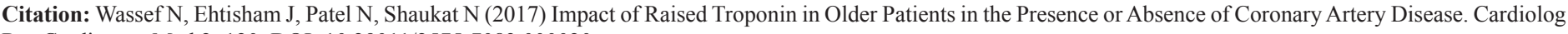
Res Cardiovasc Med 2: 120. DOI: 10.29011/2575-7083.000020

\begin{tabular}{|c|c|c|c|c|c|c|c|c|}
\hline & & \multirow{2}{*}{\multicolumn{2}{|c|}{$\begin{array}{c}\text { Non-Obstructive } \\
\mathrm{N}=115(12 \%)\end{array}$}} & \multirow{2}{*}{\multicolumn{2}{|c|}{$\begin{array}{c}\text { Obstructive CAD } \\
\mathrm{N}=847(88 \%)\end{array}$}} & \multirow{2}{*}{\multicolumn{2}{|c|}{$\begin{array}{c}\text { Relative Risk } \\
{[95 \% \mathrm{CI}]} \\
\end{array}$}} & \multirow{3}{*}{$\mathrm{P}$ value } \\
\hline & & & & & & & & \\
\hline \multicolumn{2}{|c|}{1 Month outcome } & & & & & & & \\
\hline \multicolumn{2}{|c|}{ MACCE } & 5 & $-4.30 \%$ & 51 & $-10.40 \%$ & 0.7221 & $0.29-1.77$ & 0.4771 \\
\hline \multirow[t]{3}{*}{ Death } & Total & 6 & $-5.20 \%$ & 39 & $-4.60 \%$ & 1.24 & $0.54-2.86$ & 0.6124 \\
\hline & Cardiac & 4 & $-3.40 \%$ & 30 & $-3.50 \%$ & 0.98 & $0.35-2.74$ & 0.9723 \\
\hline & Non-Cardiac & 2 & $-1.70 \%$ & 9 & $-1.00 \%$ & 1.63 & $0.36-7.48$ & 0.5252 \\
\hline \multicolumn{9}{|c|}{1 Year outcome } \\
\hline \multicolumn{2}{|c|}{ MACCE } & 15 & $-13.00 \%$ & 131 & $-15.40 \%$ & 0.84 & $0.51-1.39$ & 0.5021 \\
\hline \multirow[t]{3}{*}{ Death } & Total & 12 & $-10.40 \%$ & 95 & $-11.20 \%$ & 0.93 & $0.53-1.64$ & 0.8032 \\
\hline & Cardiac & 5 & $-4.30 \%$ & 48 & $-5.60 \%$ & 0.77 & 0.31-1.89 & 0.564 \\
\hline & Non-cardiac & 7 & $-6.00 \%$ & 43 & $-5.00 \%$ & 1.2 & $0.55-2.60$ & 0.6461 \\
\hline \multicolumn{9}{|l|}{ MI } \\
\hline & STEMI & 2 & $-1.70 \%$ & 24 & $(2.8 \%)$ & 0.61 & $0.15-2.56$ & 0.5033 \\
\hline & NSTE-ACS & 0 & $(0 \%)$ & 25 & $(2.9 \%)$ & 0.14 & $0.01-2.34$ & 0.1727 \\
\hline $\begin{array}{c}\text { Unplanned } \\
\text { revascularization }\end{array}$ & & 2 & $(1.7 \%)$ & 49 & $(5.8 \%)$ & 0.3 & $0.07-1.22$ & 0.0925 \\
\hline CVA/TIA & & 1 & $(0.8 \%)$ & 7 & $(0.8 \%)$ & 1.05 & $0.13-8.47$ & 0.9619 \\
\hline Major bleeding $\diamond$ & & 3 & $(2.6 \%)$ & 24 & $(2.8 \%)$ & 0.92 & $0.28-3.01$ & 0.8912 \\
\hline
\end{tabular}

Table 4: One month, one-year MACCE and Mortality for all patients with angiography.

\begin{tabular}{|c|c|c|c|c|c|c|c|c|}
\hline & & \multirow{2}{*}{\multicolumn{2}{|c|}{$\begin{array}{c}\text { Non-Obstructive (ONO- } \\
\text { CAD) }\end{array}$}} & \multirow{2}{*}{\multicolumn{2}{|c|}{$\frac{\text { Obstructive CAD }}{(\mathrm{OO}-\mathrm{CAD})}$}} & \multicolumn{2}{|c|}{ Relative Risk } & \multirow{3}{*}{$P$ value } \\
\hline & & & & & & & {$[95 \% \mathrm{CI}]$} & \\
\hline & & & & & $(87.3 \%)$ & & & \\
\hline \multicolumn{2}{|c|}{1 Month outcome } & & & & & & & \\
\hline \multicolumn{2}{|c|}{ MACCE } & 9 & $-13.80 \%$ & 51 & $-11.30 \%$ & 1.21 & $0.62-2.3$ & 0.56 \\
\hline \multirow[t]{3}{*}{ Death } & Total & 6 & $-9.20 \%$ & 35 & $-7.80 \%$ & 1.17 & $0.59-2.6$ & 0.69 \\
\hline & Cardiac & 4 & $-6.10 \%$ & 26 & $-5.80 \%$ & 1.06 & $0.38 / 2.9$ & 0.91 \\
\hline & $\begin{array}{c}\text { Non- } \\
\text { Cardiac }\end{array}$ & 2 & $-3.00 \%$ & 9 & $-2.00 \%$ & 1.53 & $0.33-6.9$ & 0.58 \\
\hline \multicolumn{9}{|c|}{1 Year outcome } \\
\hline \multicolumn{2}{|c|}{ MACCE } & 14 & $-21.50 \%$ & 95 & $-21.20 \%$ & 1.01 & $0.61-1.66$ & 0.95 \\
\hline \multirow[t]{3}{*}{ Death } & Total & 11 & $-16.90 \%$ & 51 & $-11.30 \%$ & 1.48 & $0.81-2.7$ & 0.19 \\
\hline & Cardiac & 8 & $-12.30 \%$ & 17 & $-3.70 \%$ & 3.2 & $1.45-7.2$ & 0.0039 \\
\hline & Non-cardiac & 2 & $-6.10 \%$ & 34 & $-7.50 \%$ & 0.81 & $0.29-2.2$ & 0.68 \\
\hline \multicolumn{9}{|l|}{ MI } \\
\hline & STEMI & 2 & $-3.00 \%$ & 17 & $(3.78 \%)$ & 0.81 & $0.1-3.42$ & 0.77 \\
\hline & NSTE-ACS & 0 & $(0 \%)$ & 21 & $(4.6 \%)$ & 0.1582 & $0.009-2.5$ & 0.19 \\
\hline $\begin{array}{l}\text { Unplanned } \\
\text { revascularization }\end{array}$ & & 0 & $(0 \%)$ & 15 & $(3.35 \%)$ & 0.21 & $0.013-2.6$ & 0.28 \\
\hline CVA/TIA & & 1 & $(1.54 \%)$ & 6 & $(1.34 \%)$ & 1.14 & $0.14-9.3$ & 0.89 \\
\hline \multicolumn{9}{|c|}{$\diamond$ Major bleeding that required blood transfusion. } \\
\hline
\end{tabular}

Table 5: One month, one-year MACCE and Mortality in Older patient with angiography. 
Citation: Wassef N, Ehtisham J, Patel N, Shaukat N (2017) Impact of Raised Troponin in Older Patients in the Presence or Absence of Coronary Artery Disease. Cardiolog Res Cardiovasc Med 2: 120. DOI: 10.29011/2575-7083.000020

The one-year MACCE rate was equivalent in both the ONOCAD and OO-CAD group (one-year MACCE: RR $[95 \% \mathrm{CI}]$ $=1.01[0.61-1.66], \mathrm{P}=0.95$. This was driven by the STEMI, NSTEMI with unplanned revascularization and stroke (1-year STEMI: RR $[95 \% \mathrm{CI}]=0.81[0.19-3.42], \mathrm{P}=0.7756),(1$-year NSTEMI: $\mathrm{RR}[95 \% \mathrm{CI}]=0.15[0.009-2.5], \mathrm{P}=0.1955)$ and $(1$-year CVA TIA: $\mathrm{RR}[95 \% \mathrm{CI}]=1.14$ [0.14-9.3], $\mathrm{P}=0.89)$. These results were also observed for the total patients who had angiography between obstructive $\mathrm{CAD}$ and non-obstructive $\mathrm{CAD}$ groups (one-year MACCE: RR [95\% CI] $=0.84[0.51-1.39], \mathrm{P}=0.52$ ). $($ Table 4 and 5)

The relative risk of the one-year mortality was also equal in ONO-CAD and OO-CAD group with a RR $[95 \% \mathrm{CI}]=1.48[0.81$ 2.7], $\mathrm{P}=0.19$. This was similar to the total patient's groups who had angiography with one-year mortality RR $[95 \% \mathrm{CI}]=0.93[0.53$ 1.64], $\mathrm{P}=0.8$. The cardiac cause of the mortality was higher in the ONO-CAD group with RR [95\% CI] $=3.2$ [1.45-7.2], $\mathrm{P}=0.0039$ ), which was not the case in the total patient's groups who had equal cardiac and non-cardiac causes for mortality at one year follow up. (Table 4 and 5)

Also, the 345 patients $>65$ years of age who had no coronary angiography (O-NA group), who were medically managed were followed, and they were found to have a longer length of stay in hospital and they had a high mortality rate with $58.8 \%$ at one year, with more non-cardiac cause of death. (Table 6)

\begin{tabular}{|c|c|c|c|}
\hline & $\begin{array}{c}\text { No } \\
\text { angiography } \\
\text { (O-NA) } \\
\text { N=345 }\end{array}$ & $\begin{array}{c}\text { Non- } \\
\text { Obstructive } \\
\text { (ONO-CAD }) \\
\text { N=65 }\end{array}$ & $\begin{array}{c}\text { Obstructive CAD } \\
\text { (OO-CAD) } \\
\text { N=448 }\end{array}$ \\
\hline Age & $83.7 \pm 7.7$ & $77.9 \pm 6.9$ & $76.8 \pm 7$ \\
\hline Gender & $184(67.1)$ & $28(43 \%)$ & $301(67.1 \%)$ \\
\hline Male & $162(32.8)$ & $37(56.9 \%)$ & $147(32.8 \%)$ \\
\hline Female & $0.73 \pm 2.11$ & $0.47 \pm 0.62$ & $2.02 \pm 3.49$ \\
\hline Troponin & $17.95 \pm 26.31$ & $11.24 \pm 17.09$ & $7.2 \pm 10.04$ \\
\hline $\begin{array}{c}\text { Length of } \\
\text { hospital stay } \\
\text { (LOS) }\end{array}$ & $203(58.8 \%)$ & $8(12.3 \%)$ & $86(19.1 \%)$ \\
\hline Mortality & $80(39.4 \%)$ & $4(50 \%)$ & $46(53.4 \%)$ \\
\hline Cardiac & $123(60.6 \%)$ & $4(50 \%)$ & $40(46.6 \%)$ \\
\hline Non-cardiac & $12(3.5 \%)$ & $2(3 \%)$ & $17(3.8 \%)$ \\
\hline STEMI & $1(0.2 \%)$ & 0 & $21(4.6 \%)$ \\
\hline ACS & $8(2.3 \%)$ & $1(1.5 \%)$ & $6(1.3 \%)$ \\
\hline CVA/TIA & & & \\
\hline
\end{tabular}

Table 6: Older patients with no angiography outcome in comparison to angiography patients.

\section{Discussion}

The current European Society of Cardiology guidelines for the management of Acute Coronary Syndrome (ACS) without ST-segment elevation promote the use of cardiac troponin assays as they allow more accurate and early diagnosis of acute myocardial infarction [11]. In several studies of ACS, troponin elevation has been associated with a worse prognosis $[12,13]$. Coronary arteriograms in these patients have revealed that approximately $80 \%$ of such patients have significant underlying CAD. The rest of the patients had no significant underlying CAD $[14,15]$. Many disease states, such as sepsis, atrial fibrillation, congestive heart failure, pulmonary embolism, myocarditis, myocardial contusion, renal failure, and critically ill patients can be associated with a raised troponin level [16-19]. The detection of the troponin in blood is an independent risk factor that identifies patients with increased mortality rate in these different clinical settings [20]. The reasons for this increase in mortality are currently poorly understood, but may be related to myocardial necrosis with myocyte loss or underlying quiescent CAD [12].

The older patients already have decreased compliance of the central arteries due to a number of age-related changes in the structural components in the artery [21-23]. These changes cause isolated systolic hypertension with a widened pulse pressure and increased after load. They have a shorter diastolic phase, during which the coronary flow occurs. Decreased coronary perfusion combined with increased afterload can lead to myocardial ischemia in the elderly patient, even without severe atherosclerotic lesions, especially with increased myocardial oxygen demand, as with Left Ventricular Hypertrophy (LVH), or decreased oxygen delivery capacity as with anemia [23-27].

Previously, two studies have investigated the causes of troponin elevations in patients with normal coronary arteriograms. In a study of 144 patients, non-ACS ischemic causes of elevated troponins included 35 patients $(24 \%)$ with tachyarrhythmia, $2(1.4 \%)$ with LV hypertrophy, $1(0.7 \%)$ with malignant hypertension, $2(1.4 \%)$ with coronary vasospasm, and 9 (7\%) with gastrointestinal bleeding [26]. In another study of 21 patients, causes of elevated troponin were tachycardia in 6 patients $(28.5 \%)$ and extreme physical exertion in 2 patients $(9.5 \%)[27,28]$. Our study showed the non-ACS presumed causes of elevated troponins in the older patients were tachyarrhythmia (20\%) respiratory failure/severe pneumonia $(10.7 \%)$ and sepsis (7.6\%), this was similar to the total patient groups who had angiography with non-significant stenosis in their coronary arteries. (Table 7 and 8) 
Citation: Wassef N, Ehtisham J, Patel N, Shaukat N (2017) Impact of Raised Troponin in Older Patients in the Presence or Absence of Coronary Artery Disease. Cardiolog Res Cardiovasc Med 2: 120. DOI: 10.29011/2575-7083.000020

\begin{tabular}{|c|c|c|}
\hline Cause & Number=65 & $(\%)$ \\
\hline Tachyarrhythmia & 13 & $(20 \%)$ \\
\hline $\begin{array}{c}\text { Respiratory failure/Severe pneu- } \\
\text { monia }\end{array}$ & 7 & $(10.7 \%)$ \\
\hline Sepsis & 5 & $(7.6 \%)$ \\
\hline Advanced Malignancy & 3 & $(4.6 \%)$ \\
\hline Heart Failure & 5 & $(7.6 \%)$ \\
\hline Acute kidney injury & 5 & $(7.6 \%)$ \\
\hline Aortic valve disease & 4 & $(6.1 \%)$ \\
\hline Takotsubo syndrome & 2 & $(3.0 \%)$ \\
\hline Brady-arrhythmia & 2 & $(3.0 \%)$ \\
\hline Aortic dissection & 1 & $(1.5 \%)$ \\
\hline Pulmonary embolism & 1 & $(1.5 \%)$ \\
\hline Suspected Vaso-spastic angina & 0 & $(\%)$ \\
\hline Critically ill with ITU admission & 0 & $(\%)$ \\
\hline Cerebrovascular Stroke & 0 & $(\%)$ \\
\hline Myo-pericarditis & 0 & $(\%)$ \\
\hline Unknown & 17 & $(26.1 \%)$ \\
\hline IHD & 0 & $(\%)$ \\
\hline Post PCI Troponin rise & 0 & $(\%)$ \\
\hline 7 Pred & 0 & $0.0 \%(n)$ \\
\hline
\end{tabular}

Table 7: Presumed Causes for raised troponin in Older Non-Obstructive CAD group.

\begin{tabular}{|c|c|c|}
\hline Cause & Number $=115$ & $(\%)$ \\
\hline Tachyarrhythmia & 25 & $(21.7 \%)$ \\
\hline $\begin{array}{l}\text { Respiratory failure/Severe pneu- } \\
\text { monia }\end{array}$ & 8 & $(6.9 \%)$ \\
\hline Sepsis & 7 & $(6 \%)$ \\
\hline Advanced Malignancy & 7 & $(6 \%)$ \\
\hline Heart Failure & 6 & $(5.2 \%)$ \\
\hline Myo-pericarditis & 5 & $(4.3 \%)$ \\
\hline Takotsubo syndrome & 4 & $(3.4 \%)$ \\
\hline Aortic valve disease & 4 & $(3.4 \%)$ \\
\hline Suspected Vaso-spastic angina & 2 & $(1.7 \%)$ \\
\hline Pulmonary embolism & 2 & $(1.7 \%)$ \\
\hline Brady-arrhythmia & 2 & $(1.7 \%)$ \\
\hline Critically ill with ITU admission & 2 & $(1.7 \%)$ \\
\hline Cerebrovascular Stroke & 0 & $(\%)$ \\
\hline Acute kidney injury & 10 & $(8.6 \%)$ \\
\hline Aortic dissection & 1 & $(0.8 \%)$ \\
\hline Unknown & 35 & $(30.4 \%)$ \\
\hline IHD & 0 & $(\%)$ \\
\hline Post PCI Troponin rise & 0 & $(\%)$ \\
\hline
\end{tabular}

Table 8: Presumed Causes for raised troponin in Total Non-Obstructive CAD group.
Interestingly, no causes were identified for the raised troponin in 35 patients from the total group with no evidence of CAD, of these 17 patients were $>65$. These patients were found to have a low risk with no mortality and a MACCE rate of 0 at one-year follow up.

In the study by Segev, et al. it was found that the incidental troponin rise was more common in older patients and was associated with a poorer prognosis compared to ACS with obstructive CAD [29]. This rise in the troponin is seen more in the elder patients is due to higher prevalence of non-ACS conditions [30]. In our study frailty was found in $81.4 \%$ of the patients who had no angiograms as were deemed clinically not suitable for invasive procedures. Those patients had more than $50 \%$ mortality within a year of admission to the hospital with a raised troponin level. This is similar to previous studies, which have shown frailty to have significant incremental hospital and 6-month mortalities and has an adverse impact of survival [31,32].

Also, a previous study by Webb et al. has found that the highly sensitive troponin (hs-TnT) elevations $(>14 \mathrm{ng} / \mathrm{L})$ were common in older patients presenting to the emergency department without ACS or other acute illnesses known to cause to troponin elevation [33]. Their multivariate analysis identified age over 70 years $(\mathrm{p}<0.001)$, as the strongest independent predictor of incidental elevated hs-TnT. This finding appeared to be independent of the higher burden of co-morbidities in this age group [34].

In our study, we found that the older patients who had nonobstructive CAD had similar MACCE and mortality to the patients who presented with obstructive $\mathrm{CAD}$, which was similar to the total groups. Interestingly, the older patients who had raised troponin and non-obstructive CAD had more cardiac causes of mortality than the ones who had obstructive coronary disease on admission, at one year follow up. Nearly a third of these patients were frail and this may have contributed to their mortality rather than coronary artery disease. (Table 4 and 5)

These findings were previously shown by the HOPE [Heart Outcomes Prevention Evaluation] which revealed that population with raised high sensitivity troponin levels were independently associated with cardiovascular death and future myocardial infarction over a mean follow up of 4.5 years [34]. Also, the Dallas Heart Study, which was a prospective observational cohort of general patients, has shown that elevated levels of high sensitivity troponin were associated with all-cause mortality within a median follow up of 6.4 years, as well as with evidence of structural heart disease, including left ventricular hypertrophy and systolic dysfunction $[35,36]$.

These findings challenge the idea that these are "False-Positive" troponin elevations and that these patients may be regarded as low risk for subsequent cardiovascular events. This elevation of troponin in these patients may have also resulted from coronary 
Citation: Wassef N, Ehtisham J, Patel N, Shaukat N (2017) Impact of Raised Troponin in Older Patients in the Presence or Absence of Coronary Artery Disease. Cardiolog Res Cardiovasc Med 2: 120. DOI: 10.29011/2575-7083.000020

athero-thrombosis, which was not evident using standard angiography or from other ischemic and non-ischemic mechanisms [11]. The presence of frailty and vascular aging increases the risk of adverse outcomes and mortality.

\section{Conclusion}

Older patients with a raised troponin and non-obstructive CAD with an identified other cause are at equivalent mortality risk at 30 days and one year to those with obstructive CAD. The potential other aetiologies for the raised troponin, were tachyarrhythmia, respiratory failure/severe pneumonia and sepsis. The patients who were medically managed were found to have raised one-year mortality.

Acknowledgement: Special gratitude to colleagues in cardiology department, Kettering General Hospital.

\section{References}

1. Agewall S, Giannitsis E, Jernberg T, Katus H (2011) Troponin elevation in coronary vs. non-coronary disease. Eur Heart J 32: 404-411.

2. Esther AP, Bockel V, Tulleken JE, Zijlstra JG (2005) Troponin in septic and critically ill patients. Chest 127: 687-688.

3. Roongsritong C, Warraich I, Bradley C (2004) Common causes of troponin elevations in the absence of acute myocardial infarction-incidence \& clinical significance. Chest 125: 1877-1884.

4. Mehta S, Morales PF, Pillai M, et al. (2007) Prognostic implications of elevated troponin in patients with suspected acute coronary syndrome with non- obstructive coronary artery disease. Circulation 116: 624.

5. Planer D, Lincoff AM, Moses JW, et al. (2011) Prognosis of patients presenting with acute coronary syndromes with elevated serum troponins \& non-obstructive coronary artery disease: the ACUITY trial. JACC 58: 387.

6. Antman EM, Tanasijevic MJ, Thompson B, Schactman M, McCabe $\mathrm{CH}$, et al. (1996) Cardiac-specific troponin I levels to predict the risk of mortality in patients with acute coronary syndromes. N Engl J Med 335: $1342-1349$

7. $\quad$ cTnT; AQT90 FLEX [Radiometer Medical ApS, Brønshøj, Denmark Radiometer Medical ApS, 2700 Brønshøj, Denmark 201: 928-982.

8. PavoneP, Leo R (2009) Evaluation of stenosis and occlusion. CT Evaluation of Coronary Artery Disease book. Verlag Italia: Springer Chapter 9: 91-97.

9. Wijns W, Kolh P, Danchin N, et al. (2010) Guidelines on myocardial revascularization. Eur Heart J 31: 2501-2555.

10. Blumenthal RS, Cohn G, Schulman SP (2000) Medical therapy versus coronary angioplasty in stable coronary artery disease: a critical review of the literature. J Am Coll Cardiol 36: 668-673.

11. Hamm C, Bassand JP, Agewall S (2011) ESC Guidelines for the management of acute coronary syndromes in patients presenting without ST-segment elevation: The Task Force for the management of acute coronary syndromes (ACS) in patients presenting without persistent ST-segment elevation of the European Society of Cardiology (ESC). Eur Heart J 32: 2999-3054.
12. Heidenreich PA, Alloggiamento T, Melsop K (2001) The prognostic value of troponin in patients with non-ST elevation acute coronary syndromes: a metaanalysis. J Am Coll Cardiol 38: 478-485.

13. Maeder M, Fehr T, Rickli H (2006) Sepsis-associated myocardial dysfunction: diagnostic and prognostic impact of cardiac troponins and natriuretic peptides. Chest 129: 1349-1366.

14. Kontos MC, Anderson FP, Ornato JP (2002) Utility of troponin I in patients with cocaine-associated chest pain. Acad Emerg Med 9: 10071013.

15. Kontos MC, Jesse RL, Tatum JL (2003) Coronary angiographic findings in patients with cocaine-associated chest pain. J Emerg Med 24: 9-13.

16. Dokainish H, Pillai M, Murphy SA (2005) Prognostic implications of elevated troponin in patients with suspected acute coronary syndrome but no critical epicardial coronary disease, a TACTICS-TIMI-18 Substudy. JACC 45: 19-24.

17. Myint PK, Al-Jawad M, Chacko SM (2008) Prevalence, characteristics and outcomes of people aged 65 years and over with an incidental rise in cardiac troponin I. Cardiology 110: 62-67.

18. Collinson PO (2012) Sensitive troponin assays. Postgrad Med J 88: 348352.

19. Nikhilesh J, Sathyamurthy I (2005) Troponins: current status in coronary artery disease. J Assoc Phys India 53: 116-118.

20. Skeik N, Patel DC (2007) A review of troponins in ischemic heart disease and other conditions. Int J Angiol 16: 53-58.

21. Lakatta EG (2007) Central arterial aging and the epidemic of systolic hypertension and atherosclerosis. J Am Soc Hypertens 1: 302-340.

22. Lakatta EG, Levy D (2003) Arterial and cardiac aging: major shareholders in cardiovascular disease enterprises: Part I: aging arteries: a "set up" for vascular disease. Circulation 107: 139-146.

23. Jackson CF, Wenger NK (2011) Cardiovascular Disease in the Elderly. Rev Esp Cardiol 64: 697-712.

24. Dart AM, Kingwell BA (2001) Pulse pressure -a review of mechanisms and clinical relevance. J Am Coll Cardiol 37: 975-984.

25. Safar ME, Levy BI, Struijker-Boudier H (2003) Current perspectives on arterial stiffness and pulse pressure in hypertension and cardiovascular diseases. Circulation 107: 2864-2869.

26. Mahajan N, Mehta $Y$, Rose M, et al. (2006) Elevated troponin level is not synonymous with myocardial infarction. Int J Cardiol 111: 442449 .

27. Bakshi TK, Choo MK, Edwards CC, Scott AG, Hart HH, et al. (2002) Causes of elevated troponin I with a normal coronary angiogram. Intern Med J 32: 520-525

28. Newby LK, Jesse RL, Babb JD, Christenson RH, De Fer TM, et al. (2012) ACCF 2012 Expert Consensus Document on Practical Clinical Considerations in the Interpretation of Troponin Elevations. J Am Coll Cardiol 60: 2427-2463.

29. Segev A, Beigel R, Goitein O (2012) Non-obstructive coronary artery disease upon multi-detector computed tomography in patients presenting with acute chest pain-results of an intermediate term follow-up. Eur Heart J Cardiovasc Imaging 13: 169-173. 
Citation: Wassef N, Ehtisham J, Patel N, Shaukat N (2017) Impact of Raised Troponin in Older Patients in the Presence or Absence of Coronary Artery Disease. Cardiolog Res Cardiovasc Med 2: 120. DOI: 10.29011/2575-7083.000020

30. Normann J, Mueller M, Biener M, Vafaie M, Katus HA, et al. (2012) Effect of Older Age on Diagnostic and Prognostic Performance of Highsensitivity Troponin T in Patients Presenting to an Emergency Department. Am Heart J 164: 698-705.

31. Le Maguet P, Roquilly A, Lasocki S, Asehnoune K, Carise E, et al. (2014) Prevalence and impact of frailty on mortality in elderly ICU patients: a prospective, multi- center, observational study.Intensive Care Med 40: 674-682.

32. Zeng A, Song X, Dong J, Mitnitski A, Liu J, et al. (2015) Mortality in Relation to Frailty in Patients Admitted to a Specialized Geriatric Intensive Care Unit. J Gerontol a Biol Sci Med Sci 70: 1586-1594.

33. Webb IG, Yam ST, Cooke R, A Aitken, PD Larsen, et al. (2012) Elevated Baseline Cardiac Troponin Levels in the Elderly-Another Variable to Consider? Heart, Lung and Circulation. Heart, Lung and Circulation 21: $520-521$.
34. Yusuf S, Sleight P, Pogue J, Bosch J, Davies R, et al. (2000) Effects of an angiotensin-converting-enzyme inhibitor, ramipril, on cardiovascular events in high risk patients. The Heart Outcomes Prevention Evaluation Study Investigators. N Engl J Med 342: 145-153.

35. Sherwood MW, Newby LK (2014) High-Sensitivity Troponin Assays: Evidence, Indications, and Reasonable Use. J Am Heart Assoc 3: e000403.

36. De Lemos JA, Drazner MH, Omland T, Ayers CR, Khera A, et al. (2010) Association of troponin $T$ detected with a highly sensitive assay and cardiac structure and mortality risk in the general population. JAMA 304: 2503-2512. 